\title{
A DELAY VIRUS MODEL WITH BEDDINGTON-DEANGELIS FUNCTIONAL RESPONSE
}

\author{
ZHiting XU AND Mingmei SU
}

\begin{abstract}
In this paper, we present a delay virus model with Beddington-DeAngelis functional response. We first introduce the basic reproduction number $R_{0}$ and the immune response reproduction number $R_{1}$, and then show that the system has three possible equilibria depended on $R_{0}$ and $R_{1}$. We further show that the global stability of the disease-free equilibrium $E_{0}$, immunefree equilibrium $E_{1}$ and endemic equilibrium $E_{2}$ are fully determined by $R_{0}$ and $R_{1}$, that is, $E_{0}, E_{1}$ and $E_{2}$ are globally asymptotically stable when $R_{0} \leqslant 1, R_{1} \leqslant 1<R_{0}$, and $R_{1}>1$, respectively.
\end{abstract}

Mathematics subject classification (2010): 94O25, 92C50, 34003.

Keywords and phrases: delay virus model, global stability; Beddington-DeAngelis functional response, Lyapunov functionals, LaSalle invariance principle.

\section{REFERENCES}

[1] J.R. BedDington, Mutual interference between parasites or predators and its effect on searching efficiency, J. Anim. Ecol., 44 (1975), 331-340.

[2] D.L. DeAngelis, R.A. Goldstein, R.V. O’Neill, A model for trophic interaction, Ecology., 56 (1975), 881-892.

[3] G. Huang, W. Ma, Y. TAKeUchi, Global properties for virus dynamics model with BeddingtonDeAngelis functional response, Appl. Math. Letters., 22 (2009), 1690-1693.

[4] G. HUANG. W. MA, T. TAKEUCHI, Global analysis for delay virus dynamics model with BeddingtonDeAngelis functional response, Appl. Math. Letters., 24 (2011), 1199-1203.

[5] G. HUANG. Y. TAKEUCHI, W. MA, Lyapunov functionals for delay differential equations model of viral infection, SIAM J. Appl. Math., 70 (2010), 2693-2708.

[6] J.K. HAle, S.M. VerduYn Lunel, Introduction to Functional Differential Equations, SpringerVerlag, New York, 1993.

[7] V. Herz, S. Bonhoeffer, R. Anderson, R.M. May, M.A. Nowak, Viral dynamics in vivo: limitations on estimations on intracellular delay and virus delay, Proc. Natl. Acad. Sci., USA. 93 (1996), 7247-7251.

[8] A. Korobeinikov, Global properties of basic virus dynamics models, Bull. Math. Biol., 66 (2004), 879-883.

[9] A. Korobeinikov, Global properties of infectious disease models with nonlinear incidence, Bull. Math. Biol., 69 (2007), 1871-1886.

[10] D. LI, W. MA, Asymptotic properties of a HIV-1 infection model with delay, J. Math. Anal. Appl., 335 (2007), 683-691.

[11] M.Y. LI, H. SHU, Global dynamics of an in-host viral model with intracelluar delay, Bull. Math. Biol., 72 (2010), 1492-1505.

[12] M.Y. LI, H. SHU, Multiple stable periodic oscillations in a mathematical model of CTL response to HTLV-I infection, Bull. Math. Biol. 73 (2011), 1774-1793.

[13] C.C. MCCluskey, Complete global stability for an SIR epidemic model with delay-distributed or discrete, Nonlinear Analysis: Real World Applications., 11 (2010), 55-59.

[14] C.C. MCCLUSKey, Global stability for an SIR epidemic model with delay and nonlinear incidence, Nonlinear Analysis: Real World Applications., 11 (2010), 3106-3109. 
[15] Y. NAKATA, Global dynamics of a viral infection model with a latent period and BeddingtonDeAngelis response, Nonlinear Analysis., 74 (2011), 2929-2940.

[16] Y. NAKATA, Global dynamics of a cell mediated immunity in viral infection models with distributed delays, J. Math. Anal. Appl., 375 (2011) 14-27.

[17] P. Nelson, J. Murray, A. Perelson, A model of HIV-1 pathogenesis that includes an intracellular delay, Math. Biosci., 163 (2000), 201-215.

[18] P. Nelson, A. Perelson, Mathematical analysis of delay differential equation models of HIV-1 infection, Math. Biosci., 179 (2002), 73-94.

[19] J. PRÜSS, R. SChNAUBELT, R. ZACHER, Global asymptotic stablity of equilibria in models for virus dynamics, Math. Model. Nat. Phenom., 3 (2008), 126-142.

[20] H.L. Smith, Monotone Dnamical Systems: An introduction to the Theory of Competitive and Cooperative Systems, AMS, Providence, RI, 1995.

[21] J. WANG, L. GUAN, Global stablity fro a HIV-1 infection model with cell-mediated immune response and intracellular delay, Discrete Contin. Dyn. Syst., Ser.B., 17 (2012), 297-302.

[22] K. WANG, W. WANG, H. PANG, X. Liu, Complex dynamic behavior in a viral model with delayed immune response, Physica, D., 226 (2007), 197-208.

[23] X. WAng, Y. TAO, X. Song, A delay HIV-1 infection model with Beddington-DeAngelis fuinctional response, Nonlinear Dyn., 62 (2010), 67-72.

[24] X. WANG, Y. TAO, X. Song, Global stability of a virus dynamics model with Beddington-DeAngelis incidence rate and CTL immune response, Nonlinear Dyn., 66 (2011), 825-830.

[25] Z. WANG, R. XU, Stablity and Hopf bifurcation in a viral infection model with nonlnear incidence rate and delayed immune response, Commun Nonlinaer Sci Numer Simulat., 17 (2012), 964-978.

[26] H. ZHU, X. Zou, Dynamics of a HIV-1 infection model with cell-mediated immune response and intracelluar delay, Discrete Contin. Dyn. Syst., Ser.B., 12 (2009), 511-524. 